\title{
Disposition Category
}

National Cancer Institute

\section{Source}

National Cancer Institute. Disposition Category. NCI Thesaurus. Code C83245.

A classification of disposition data. 